\title{
O PRZYCZYNACH ZANIKU DIAKONATU STAŁEGO W KOŚCIELE ZACHODNIM
}

W opracowaniach poświęconych historii diakonatu stałego 1 pierwsze cztery wieki chrześcijaństwa traktuje się jako okres niezwykłego rozkwitu tej posługi. Wprawdzie do IX w. włącznie można mówić o obecności diakona stałego w Kościele Zachodnim, to jednak już w V w. nie jest "l'homme de la charité", by w końcu okazać sie stopniem przejściowym do święceń prezbiteratu.

Mozna zatem pytać o przyczyny zaniku diakonatu jako posługi stałej w Kościele Zachodnim. Ze zrozumiałych względów nie można będzie zatrzymać się na samej zjawiskowej warstwie zagadnienia, tzn. samym odnotowaniu tylko faktów. Należy bowiem postawić sobie wymagania dalej idące, a mianowicie dác odpowiedź na pytanie, co doprowadziło do jego upadku.

o czasie rozwoju i znaczenia tej posługi, jak i przyczynach upadku pisał Paweł VI w motu proprio "Ad pascendum" ${ }^{2}$. W piśmie tym wymienia jedynie dwie przyczyny zaniku diakonatu stałego: zakaz udzielania święceń z pominięciem kolejnych stopni i brak atrakcyjności posługi diakońskiej. Uwagi te naleźy dołączyć do wskazanych przez J. P. Gabus czterech powodów wyjaśniających schyłek tej posługi:

1 Por. W. Croce, Aus der Geschichte des Diakonates, w: Diaconia in Christo, Hrsg. K. Rahner, H. Vorgrimler, Freiburg-Basel-Wien $1962,92-128 \% 112 /$; P. Winninger, Les diacres. Histoire et avenir du diaconat, Paris 1967, 27-61/41-48/; C. Bridel, Aux seuils de l,espérance. Le diaconat en notre temps, Neuchatel 1971, 27-34; W. Meslin, Instytucje kościelne i klerykalizacja w Kościele starożtnym, w: Socjologia religii. Wybór tekstów, Oprac. F. Adamski,
Kraków 1983, 94-103.

2 Tłum. polskie E. Sztafrowskiego, w: Posoborowe Prawodawstwo Kościelne, V/2, Warszawa 1974, 22-26. Tak swoiście rozumiany diakonat, w ostatecznym s formuł owaniu nawiązujący do typologii Ignacedrei Jahrhunderten der Kirche, in: zakłada istnienie Kościoła jako wspólnotyla in Christo, s. 23-30/ hat Jesus Gemeinde gewollt? 2. Aufl., Freiburg i.Br. 1984/。 
zapoznanie przez Kościół odpowiedzialności czysto diakonalnej, rozwój zakonów, walke o precedencję z prezbiterami, podboje muzuzmanskie ${ }^{3}$. Wydaje się, ze wskazanie $i$ opisanie tych przyczyn nie może wyczerpać złozonej problematyki zanıku tego urzędu; w 1stocie boพ1em jego wyjaśnienie pragniemy sprowadzić do ogólnie tu sformułowanego stwierdzenia: instytucjonalizacji religil 1 Kościoła, a co za tym idzle takze jego klerykalizacj 1 .

\section{DYLEMATY INSTYTUCJONALIZACJI RELIGII}

To instytucje społeczne - czy tego chcemy, czy nie, a nie wybitne czyny charyzmatycznych przywódców zapewniają ciągłość wmieniającyin się świecie. Także religia, której początki wiążą się z.charyzmatycznym działaniem jej przywódcy, jeśli chce przetrwać, mus 1 ulec procesowi rutynizacji. Thomas 0'Dea stwierdza, ze ów nieunikniony proces społeczny stawia piéć charakterystycznych dylematów. One to wyjaśniają napięcie zachodzące pomiędzy instytucją a charyzmatem, a takźe tłumaczą jednostronności zachowan lub przyczyn regresu, a nawet zaniku pewnych posług kościelnjch ${ }^{5}$.

Instytucjonalizacja jakiegoś ruchu religijnego wywołuje dylemat mieszanej motywacji, tzn. istnienia egocentrycznych 1 bezinteresoinych uzasadnień określonego działania, postępku ludzkiego. W wypadku chrześcijaŕstwa przykład tak charakterystycznego dylematu mamy poświadczony u Marka $/ 10,35-45 /{ }^{6}$.

Także służba Boża musi byé poddana obiektywizacji, aby ustrzec się wyobcowania. Procesowi temu towarzyszyć będzie zawsze dylemat symboliczny, tzn. rutyna może byé tak daleko posunięta, że nie

3 Diakonia Bibli1, "Novum" $1979 \mathrm{nr} 4-5,18-35 / 31-32 /$.

4 Ważne wydają się tu następujące opracowania: T. F. 0'Dea, Pię́ dylematów instytucjonalizacji religil, w: Socjologia religil,

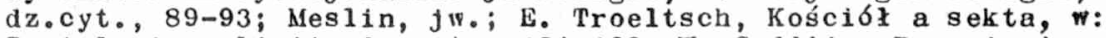
Socjologia religi1, dz.cyt., 104-109; W. Goddijn, Rozwazania socjologiczne o zróznicowaniu grup w obrębie chrześcijaŕstwa, tamże, 110-118; F. Füstenberg, Struktura Kościoła 1 społeczeństwa, tamze, 119-129.

5 Piéć dylematów 1nstytucjonalizacji, art.cyt., 89.

6 Por. G. Lohfink, dz.cyt., 57-63, 134-142. 
พytwarza harmoní pomiędzy aktem zewnętrznym a wewnętrznym przeżyc1em.

Niezwykle interesujące spostrzeżenia zawierają uwagl tyczące rutynizacji charyzmatycznego przywództwa w kompleksie urzędów /dylemat porządku administracyjnego/: "Kościół katolicki jest tego najlepszym przykładem. Ta biurokratyczna struktura stwarza nowe urzędy, jésll tylko wyłonlą sie nowe problemy. "W ten sposób sama stwarza sob1e komplikacje: rychło bowiem rodzą się trudności na tle kompetencj1 1 niejasnych definicji uprawnień 1 funkcji"7? Nie będę ukrywał przekonania, że ta właśnie uwaga interesować będzie nas najbardziej 1 wokół niej właśnie skoncentrujemy całość refleksji pomieszczonych w tym punkcie.

Pozostałe dwa dylematy dotyczą legalizmu/skądinąd pożyteczne ujęcı postępowania moralnego w kodeks reguł/ towarzyszącego zazwyczaj przeakcentowaniu urzędu /dylemát ograniczenta/ oraz wprowadzenia na miejsce nawrócenla długotrwałego procesu szkolenia 1 nauczania młodej generacji /dylemat mocy i nawrócenia jako przeciwieństwo przymusu/.

Za zwróceniem uwagi na dylemat porządku administracyjnego przemawia towarzyszący diakonatowi stałemu od początku niezbyt ostro zarysowany zakres kompetencji, uprawnień i funkcji. Zwrócenie uwagi biblistów na nowotestamentalny przekaz o ustanowieniu diakonów 1 o diakonach z listów św. Pawła /Dz 6, 1-6; Flp 1, 1; $1 \mathrm{Tm} \mathrm{3,8-12/,}$ zrodził problem tzw. identyfikacji Siedmiu z diakonami ${ }^{8}$. A i do dziś

7 0'Dea, art.cyt., 91.

8 M. Marczewski, Historia diakonatu stałego w Kościele pierwotnym, "Novum" 1979 nr 4-5, 49-58. Warto zwrócić uwage na interesującą sugestię Cz. Bartnika, tycząca rozwiazania problemu identyfikacji: "Jednakze diakonat podlegał daleko 1dącym model owantom i zmianom. Dlatego tekst ten /Dz 6, 1-7 - uwaga moja: M. M./ nie oznacza bynajmniej pierwszego momentu pojawienia się diakonatu, przynajmniej w późniejszym, wyksztaltowanym sensie. " Flp 1,1 11 Tm 3, 8-13 diakoni to zwyczajni posługujący gminte w dziedzinie charytatywnej 1 podobnie sw. Lukasz zacząt interpretowac jerozolimskie powołanie owych Siedmiu /Dz 6, 1-2/. Widocznie diakonat hellenistyczny miał wezszy zakres i ograniczał sie raczej do dzlałalności charytatymnej. Natomiast w Jerozolimie diakonat by dużo wcześniejszy niż opisany w Dz 6, 1-7, 1 obejmował, prócz charytatywnych, takze Punkcje sakralne, diakoni prowadzą doktrynalne dysputy z żdami, prowadzą ewangelizację, głoszą kerygmę Chrystusową, świadczą o Chrystusie życiem 1 czynami, udz1elają chrztu /Dz 6, 4-14; 8, 5-13. 26-40/. Siedmiu wybranych hellenistów 
Jesté́my śwladkami zdecydowanej opozycji niektórych teologów, wykorzystujących 6 w brak wyraźnego opisania specyliki posługi 9.

Powyzsze uwagi uprawniaja do sformułowania dwu tez, które znamionują w interesującym nas względzie rozwój pierwotnego Kościoła: dość wcześnie doszło do 1 nstytucjonalizacji diakonii; - w zależności od przewagl jednej z tré́c1 motywacyjnych /egocentrycznej lub bez1nteresownej/ może dochodzić do przeobrażenia 1 zaniku pierwotnych cech instytucji lub rozwinięcia się cech reformistycznych 1 ruchóm reformacyjnych.

Oczywície, nie można przyjęcien tych uwag w całości wytłumaczyć zaniku diakonatu stałego. Pewne jest natomiast, że można je udowodnic, 1 ze stoją obok procesu klerykalizacji Kościoła u podstaw przeobrazenia diakonatu stałego w stopień przejściowy do przyjęcia święceń prezbiteratu w Kościele zachodnim.

\section{KLERYKALIZACJA}

Michel Mesiln stwierdza, ze począwszy od poł. III w. "instytucjonalizacja Kościoła w cesarstwie przybiera na sile i doprowadza do pewnej klerykalizacji"10, tzn. izolacji duchownych od świeckich. W przypadku diakonatu rozwój prezbiteratu sprawia jego stopniowe ograniczenie do funkcji paraliturgicznych i wprowadzenia zależności także od kapłanów oraz uczynienia zeń stopnia przejściowego do święceń prezbiteratu.

Od początku V stulecia spotykamy się jeszcze z jednz̨ niebezpieczną 1nnowacją, która doprowadza do pomniejszenia wartości diakonatu stałego i traktowania go jako swoiscie rozumianej kary nałożonej na duchownych żyjących w związu małżeńskim: Na Zachodzie

nie zainicjowało funkcji diakonatu w ogóle, lecz weszli oni w Punkcję już wykonywaną przez żydów palestyńskich, którzy mie11 "zaniedbywać hellenistów przy codziennym rozdawaniu jałmuźny" /Dz 6, 1/. Było to więc raczej rozszerzenie instytucji palestyńskiej diakonatu na hellenistyczne kręgi eklezjalne. Dokładny czas i sposób ustanowienia diakonatu jerozolimskiego nie jest znany"/Kościół Jezusa Chrystusa, Wrocław 1982, 228/.

9 Por. F. Klostermann, Die pastoralen Dienste heute, Linz-WienPassau 1980, 70,85.

10 Instytucje kościelne 1 klerykalizacja, art.cyt., 94-95. 
w myśl rozporządzeń synodów Turynie $/ 401 \mathrm{r} . /^{11} 1$ w Orange /441 $\mathrm{r} . /^{12}$ nie może być wyświęcony na kapłana taki diakon źonaty, który w dalszym ciągu prowadzi życie małżéskie. Jest to oczywiście konsekwencja przejęcia sformułowán synodu w Elwirze /ok. 300 r./13. Tego typu ograniczenta mogły mieć miejsce w sytuacji uznania diakonatu jako stopnia przejściowego.

Równocześnie dochodzi do powolnego zaniku rozumienia Kościoła w kategoriach wspólnoty. Jej wyraz stanowiło m.in. przekazywanie osobistych środków pienięźnych na użytek wspólnoty. Dysponowanie nim1 było jednym z zadá́ diakonów. "Jednakże na skutek interesujacego nawrotu do zиyczajów dawnego Izraela oflary te były rozumiane jako instytucja przymusowa, dziesięcina, którą ma uiszczać cały lud Bozy, przeznaczona na potrzeby kleru. Wkrótce ci wierni, którzy nie mywiazują się z tego obowiązku, podlegają klątwien"14.

\section{III. "DE IACTANTIA ROMANORUM LEVITARUM"}

- takim właśnie tytule powstałe ok. 376 r. dziełko Ambrozjastra ${ }^{15}$, jak również podobny w wymowie 1 argumentacji 146 list św. Hieronima do Ewangeliusza prezbitera ${ }^{16}$ stanowia poświadczenie dokonanej w łonie ordo instytucjonalizacji, w której pierwszorzędną rolę odgrywają motywacje egoistyczne. Oba pisma mająna celu wykazanie na podstawie Pisma św. podrzędnej roll diakona/lewity/wobec prezbitera/kapłana/. Nie są przy tym pozbawione inwektyw. Ambrozjaster uważa, że rzymscy diakoni "kierują się pozorami" 1 poddani są "głupocie 1 przechwalstwu". Podobnie Hieronim rozpoczyna swój list: "U Izajasza /32, 6/ czytamy: 》głupi wygłasza niedorzeczności《. Tak u Ambrozjastra, jak 1 Hieronima interesujące jest to, że pragną podporządkować diakona

11 Concilium Taurinense, c. 8, Mansi III 862.

12 Concilium Arausicanum I, c. 24, Mansi VI 439-440.

13 Concilium E'liberitanum, c. 33, Mansi II 11. Por. J. Lécuyer, Der Diakonat nach den kirchlichen Lehrlusserungen, in: Diaconia in Christo, dz.cyt., 213-214 przyp. 39 .

14 J. Lécuyer, dz.cyt., 96.

15 CSEL 50, 193-198.

16 CSEL $56,308-312$. 
prezbiterowi, a to z tej racji, że obaj stawiają znak równości pomiędzy prezbiteratem a episkopatem. Wprawdzie uzasadnienie jest różne, ale nie wykluczające się. Hieronim powołuje się na Flp 1, 1 /gdzie św. Paweł wymienia tylko biskupów i diakonów/ lub na te miejsca Nowego Testamentu, które wskazują na zlanie się prezbiterialnego 1 episkopalnego porządku /Dz 20, 28; Tt 1, 5-9/. Ambrozjaster zaś świadom różnicy między biskupem a prezbiterem, podkreśla bardzo mocno, że obaj są kapłanami. Tak więc 1 jednemu 1 drugiemu chodzi o to, by diakoni rzymscy przyjęli do świadomości fakt, że w gradacji święceń zajmują miejsce po prezbiterach oraz, że są sługami tak biskupów, jak 1 prezbiterów. Jednocześnie wskazują na przejściowy charakter urzędu: "z diakonów winien być ordynowany prezbiter"17.

Moźna pytać, jak mogło dojść do tak dramatycznego 1 drastycznego zarazem zaznaczenia opozycji. Wydaje się, że złożyło się na to wiele przyczyn, a walka o precedencje nie wydaje sie w tym wypadku najwaźniejsza ${ }^{18}$. Istotne w tym przypadku okazuje się przeobrażenie pierwotnych celów instytucj 1 diakonatu, a nawet jego rozkład:

- na przełomie IV i V w. nie spełniają diakoni w dziedzinie caritasu tak wiodacej roli. Powstałe wówczas diakonie ${ }^{19}$ były prowadzone przez mnichów lub świeckich;

- tak samo dzieje się z prowadzeniem ksenodochi1. Kierowali nim1 prezbiterzy lub klerycy niższych święceń ${ }^{20}$;

- doszło do tego, że synod kzymski z 595 r. gani jako anomalię dążenie diakonów do pełnienia roli śpiewaków zamiast troszczących się

17 Por. W. Croce, art.cyt., 112-124; B. Domagalski, Romische Diakone im 4. Jahrhundert - Zum Verhaltnis von Bischof, Diak on und Presbyter, w: Der Diakon. Wiederentdeckung und Erneuerung seines Dienstes, Hrsg. von J.G. Plyger, H. J. Weber, 2. Aufl., Freiburg-Basel-Wien $1981,44-56$.

18 Swiadczy o tym chociażby c. 50 synodu w Arles z $314 \mathrm{r}$. Mansi II 473 / czy c. 18 Soboru Nicejskiego z $325 \mathrm{r}$. /Mansi II 676/. Uwagi te zostały przejęte przez,późniejsze synody w Toledo z 633 r. /c. 39, Mansi X 629\% por. Lécuyer, dz.cyt., 216 przyp. 52-53.

19 H. Kamiński, Diakonia, EK III 1249-1250.

20 Por.W. Croce, art.cyt., 114-115, przyp. 168-177. 
o biednych, a z końcem IV w. zarząd nad dobrami kościelnymi musieli biskupi przekazać w ręce świeckich ekonomów.

Niewątpliwie pozostawienie powyżsych stwierdzeń bez odpowiadających opinii przeciwnych doprowadziłoby do jednostronnego 1 krzywdzącego obrazu posługi diakońskiej w okresie wyraźnego spadku jej znaczenia wościele Zachodnim. Zauważyé jednak należy, że liturgiczne jedynie ujęcie i rozumienie służby diakońskiej 1 traktowanie ich w duszpasterskiej posłudze jako koniecznego dopełnienia prezbiterów, stanowiło o wyraźnym upadku posługi i utracie żywotnego znaczenia wościele.

Pierwsze cztery wieki chrześcijaństwa stanowią dla historil diakonatu stałego okres rozkwitu. Niektórzy z badaczy każą już w dokonującym się od poł. III w. procesie instytucjonalizacji Kościoła 1 jego klerykalizacji upatrywać przyszłych znamion zaniku diakonatu jako permanentnej posługi Kościoła. Z kolei socjologiczna anal1za dylematów, jakie niesie w sobie instytucjonalizacja, a szczególnie zwrócenie uwagi na fakt zrozumiałego skądinąd przeobrażenia się charyzmatycznego przywództwa w biurokratyczną strukturę urzędów, tworzącą nowe urzędy o nieostrym zarysowaniu kompetencji $i$ uprawnień, tłumaczy wymownie wskazywane w literaturze przedmiotu przyczyny zaniku diakonatu stałego.

Niewątpliwe 1 dokonane na mocy uchwał Soboru Watykańskiego II wznowienie posługi nie jest pozbawione jednostronności. Miejmy nadzieję, że płynąca z głębi wieków nauka pozwoli na dokładniejsze określenie miejsca 1 roli diakona stałego w posłudze Kościoła, a prze. de wszystkim na wypracowanie jego diakonalnego obrazu.

$$
\text { Marek Marczewski - Lublin - Suwałkl }
$$

\section{DIE URSACHEN DES VERSCHWINDENS DES STÄNDIGEN DIAKONATS IN DER ABENDLANDISCHEN KIRCHE /Zusammenfassung/}

Die ersten Jahrhunderte des Christentums waren eine Blttezeit in der Geschichte des stindigen Diakonats. Einige Forscher wollen bereits im seit Mitte des 3. Jahrhunderts ablaufenden Prozess der Institutionalisierung und Klerikalisierung der Kirche de Vorzeichen fur Verschwinden des Diakonats als eines permanenten Dienstes der Kirche erblicken. Die soziologische Analyse der Dilemmas, die die Institutionalisierung mit sich bringt, und insbesondere der Hinweis auf die woanders verstandliche Umgestaltung der charismatischen 
Fuhrung in eine butrokratische Ämterstruktur, die neue Ämter mit unscharfer Abgrenzung von Kompetenzen und Berechtigungen schuf, erklart beredt die in der Literatur zu diesem Gegenstand aufgezeigten Ursachen des Verschwindens des standigen Diakonats.

Zweifelsohne ist auch die kraft der Beschlasse des 2. Vatikan1schen Konzils geschehene Wiedereinführung des Dienstes nicht frei von Einseitigkeit. Wir wollen hoffen, dass die aus der Tiefe der Jahrhunderte stromende Lehre eine genauere Bestimmung von Platz und Rolle des standigen Diakons im Dienst der Kirche und vor allem eine Herausarbeitung seines Diakonalen Bildes ermoglicht. 